forestry, agriculture and water supply are all cooperating. This method has also been used in the Colonies, and its general employment was discussed at the Quebec Conference on Food and Agriculture.

One point brought out during the discussion was the disparity now existing between wealthy and poor territories in regard to expenditure on science and its applications. Thus in Malaya, the expenditure on medical and health services is about 5s. a head of population, while in India, it varies from about $2 d$. to $1 s$. according to district.

The need for co-operation between scientific workers in the Dominions and the Colonies was stressed. Here the Empire Scientific Conference, which is to be held in 1946, holds out great promise.

Another need is for the raising of the status of the scientific worker in Colonial government service, so that he can occupy the same sort of position as a research worker in a good university at home. One way in which this could be achieved might be by having in each territory or regional group of territories a director of research, who would also be scientific adviser to the Government concerned, and to whom scientific workers in all fields should have direct access.

One of the most urgent problems in India and the Colonies is the study of industrial processes which can be utilized locally. Thus the conversion of molasses into industrial alcohol could be undertaken in sugargrowing countries, and the setting up of plants for extracting oil from oilseeds in Africa would provide large amounts of cattle food urgently required there. In this connexion, the decision to found a Microbiological Research Station in the West Indies is of great importance.

The discussion proved of great interest in focusing informed opinion on the urgent problems of research in India and the Colonies.

\section{SWEDEN'S WATER-POWER RESOURCES}

$\mathrm{D}$

URING the War, sixty new power stations were built in Sweden, several of more than $40,000 \mathrm{~kW}$. rating. The production of hydro-electric power in 1944 was 12,417 million $\mathrm{kWh}$., and water-power plants now total about $2,500,000 \mathrm{~kW}$. Further plants totalling about $600,000 \mathrm{~kW}$. will be completed towards 1950, and works have been started for an additional $350,000 \mathrm{~kW}$. The energy utilized in 1944 was 10,573 million $\mathrm{kWh}$., of which 4,428 million $\mathrm{kWh}$. were taken by the large industries for engine power, etc., while the electro-chemical and thermo-electric industries consumed 1,891 million $\mathrm{kWh}$. About 1,040 million $\mathrm{kWh}$. were used for traction purposes and 2,017 million $\mathrm{kWh}$. for domestic purposes, etc. 1,093 million $\mathrm{kWh}$. were used for electric steamgeneration at night-time and during non-working hours.

Plants built during the War cost about $£ 17,647,000$, and subsequent investments amount to about $£ 3,530,000$ a year.

During 1944, plant additions amounted to 280,000 $\mathrm{kW}$. Plants for a further $46,000 \mathrm{~kW}$. will probably be completed before the end of 1945. Among the new power-works to be completed within the next five years or so are those at Hjälta $(120,000 \mathrm{~kW}$.), Forsmoforsen $(75,000 \mathrm{~kW}$.), and Nämforsen $(46,000$ kW.), situated on the Angerman River with the tributary Fax River. One station of $46,000 \mathrm{~kW}$. will be built at Skedvi on the Dalälven River and one of $34,000 \mathrm{~kW}$. on the Ljusnan River.

A new station at the Harspranget waterfall in the Lule River will have a capacity of $250,000 \mathrm{~kW}$. The Suorva Dam at the Stora Lulevatten, the well-lake of the Lule River, has created a water storage with a maximum capacity of 113,000 million $\mathrm{cu}$. ft. and a regulating height of $191 \mathrm{ft}$. for the new station as well as for the existing Porjus plant.

The total Swedish water-power resources which can be exploited economically is estimated to correspond to about 36,000 million $\mathrm{kWh}$., of which one third has been utilized, while the second third is now being gradually taken into use. The last third will, however, be comparatively expensive to develop.

The networks of all the large power-plants are interconnected, and four heavy copper and steelaluminium transmission lines, stretching from the north of Sweden down through the whole country, constitute the arteries through which a large part of the country's electric energy is being supplied to industries, railways and households.

\section{NON-METALLIC DEPOSITS OF THE U.S.S.R.}

A NEW publication by the Academy of Sciences of the U.S.S.R., "Non-metallic Deposits of the U.S.S.R." (published in Russian), is planned on a large and comprehensive scale. Judging by the volume at hand (Vol. 2, 1943) this publication will extend over a number of volumes and greatly exceed a similar work published in four volumes during 1926-29, as the subjects discussed in the present volume cover 449 pages as compared with 96 pages of the previous edition. Volume 2 contains the following articles, each written by a specialist or a group of specialists on the given subject: (1) basalt and diabase, (2) barite and witherite, (3) beryl, (4) turquoise ("Biruza" in Russian), (5) bitumens and bitumenous rocks, and (6) bauxite. Each section comprises the following items: general description of the material and its mode of occurrence and genesis, localities where it is found, especially those in the U.S.S.R., methods of extraction and technology, economic statisties and bibliography.

The value of this work is manifold. First, because it gives a very full account of the localities and mode of occurrence of mineral deposits, especially those found in the Soviet Union, secondly because it provides new and interesting interpretations of data, classification, genesis and novel industrial uses. Such, for example, is the article by A. S. Ginsberg on basalt and diabase (dolerite), rocks which are extremely abundant in Britain and used mainly for road-metal, while in the Soviet Union, at the present time, they are also used for manufacturing electrical insulators, acid-resisting tanks and many other articles of industrial value, in the form of the so-called 'cast basalt'. The section on bitumens, written by a group of specialists, is of exceptional interest, especially the part written by V.A. Uspensky on the genesis and genetic classification of bitumens and also that written by A. P. Vinogradov on the occurrence of certain chemical elements, such as vanadium, nickel and uranium, in bitumens. Sections describing the occurrences of bitumens in the U.S.S.R. and the technology of bituminous products are also very interesting. The prospecting for bauxitic ores in the 
U.S.S.R. has been carried out on a very extensive scale during the last two decades, and the collection of articles on this subject provides a valuable summary of the results achieved as it gives detailed accounts of the various new bauxite localities of the Urals, Kazakhstan, Siberia and Central Asia.

On the whole, this publication, of which many more volumes are projected, promises to serve as an authoritative reference book to the mineral resources of the U.S.S.R. ; it is of interest to geologists, miners and technologists of all countries, provided that they are familiar with the Russian language.

S. I. TOMKEIEFF.

\section{FORTHCOMING EVENTS}

Thursday, December 27

ROYAL INSTITUTION (at 21 Albemarle Street, London, W.1), at 2.30 p.m.- Sir Robert Watson-Watt, F.R.S.: "Wireless"'(Christmas Lectures adapted to a Juvenile Auditory, 1).

Friday, December 28

INSTITUTE OF WELDING, EAST SCOTIAND BRANCH (at the HeriotWatt College, Chambers Street, Edinburgh), at 7.30 p.m.-Mr. F. Clark: "Non-Ferrous Welding".

\section{Saturday, December 29}

ROYAI INSTITUTION (at 21 Albemarle Street, London, W.1), at .30 p.m.- - Sir Robert Watson-Watt, F.R.S.: “Wireless"' (Christmas Lectures adapted to a Juvenile Auditory, 2).

\section{APPOINTMENTS VACANT}

APPLICATIONS are invited for the following appointments on or before the dates mentioned

ENGINEERING AssISTANTS (2) in the Borough Engineer's Department-The Town Clerk, Municipal Buildings, West Hartlepool (December 29).

LABORATORY STEWARD at the Swindon Technical Institution and Secondary School-The Director of Education, Education Office, Civi Offices, Swindon (December 29).

Mechanical ENgINEER (to organize and supervise the design and manufacture of machinery for use on Peat Bogs)- The Secretary,
Turf Development Board, Ltd., 21 Fitzwilliam Square, Dublin (December 31).

TEACHER (full-time) OF ENGINEERING WORKSHOP PRACTICE-The Principal, Twickenham Technical College, Egerton Road, Twickenham, Middx. (December 31).

Assistant MASTER with qualifications in Mathematios, Physios, OF ENGINERRING, a LEOTURER IN BIOLOGY, and a LECTURER IN MECHANICAL ENGINEERING, in the Denbighshire Technical College-The Director of Education, Education Offices, Ruthin, Denbighshire (January 5)

Engineming Assistant, Grade E, in the Public Works Department-The Borough Engineer and Surveyor, Council House, Walsall, Staffs. (January 7).

City EngInerer AnD Surveror-The Town Clerk, Town Clerk"s Office, Bradford, endorsed "City Engineer and Surveyor" (January 8). CIVIL ENGINEER (with special experience in Building), MEOHANICAI ENGINEERs (with Works and Design experience), and MECHANIOAI DRAUGHTSMEN (with Works Training and experience in Machine Design)-The Secretary, Turf Development Board, Ltd., 21 Fitzwilliam Square, Dublin (January 10).

DrRECTOR OF RESEARCH to take charge of a Research Laboratory DIRECTOR OF RESEARCH to take charge of a Research Laboratory
to be set up in the Midlands for the British Sugar Corporation-The to be set up in the Midlands for the British Sugar Corporation-The Technical and Scientiflc Register, Room 670, York House, Kingsway, ondon, W.C.2, quoting F.5532.XA (January 11)

PRINCIPAI OF THE DUNDEE TECHNICAL COLIEGE-The Clerk and Treasurer, Dundee Technical College, Bell Street, Dundee (January 12). AssISTANT ENGINEER-The Secretary, Burnham, Dorney and Hitcham Waterworks Company, High 'Street, Burnham, Bucks. January 12)

ELECTRIOAL ENGINEER AND MANAGER of the Brighouse Electricity Undertaking-The Town Clerk, Town Hall, Brighouse, endorsed 'Electrical Engineer and Manager' (January 16).

TEACHER (full-time) OF STRUCTURAT ENGINEERING SUBJECTS at the Brixton School of Building, Ferndale Road, Iondon, S.W.4-The Education Officer (T.1), County Hall, London, S.E.1 (January 16).

TEACRERS (full-time) OF MECHANICAL ENGENEERING SUBJECTS a the South-East London Technical Institute, Lewisham Way, London,
S.F.4-The Education Officer (T.1), County Hall, London, S.E.1 (January 18).

Principal of the County Technical College, Dartford, and REgIONAL PRINCIPAL FOR TECHNIOAL EDUCATION in the area served by the College-County Education Officer, Kent Education Committee, Springfield, Maidstone (January 23).

PHYSICAL CHEMISTS or PHYSICISTS in connexion with development of Plasties-The Ministry of Labour and National Service, Appointments Department, Technical and Scientific Register, Room 670 York House, Kingsway, London, W.C.2, quoting F.5261.XA (January $25)$.
Lecturer in Mechanical Engingering (Ref. No. C.2931.A), a LECTURER IN EIECTRICAL ENGINEERING (Ref. No. D.1557.A), a LEOTURER IN WIRELESS ENGINEERING (Ref. No. D.1558.A), a LECTURER in INSTRUMENTS TEOHNOLOGY (Mechanical) (Ref. No. C.2978.A), and a LECTORER IN INSTRUMENTS TECHNOLOGY (Optical) (Ref. No. C.2979.A), under the Military College of Science, Stoke-onTrent-The Ministry of Labour and National Service, Appointments Department, Technical and Scientiflc Register, Room 670, York House, Kingsway, London, W.C.2, quoting the appropriate Ref. No.
(January 26).

IILUMINATION ENGINEER to undertake development work on the application of plastics in the lighting fleld-The Ministry of Labour and National Service, Appointments Department, Technical and Scientiflc Register, Room 670, York House, Kingsway, London, W.C.2, quoting D.1629.XA (January 28).

SECRETARY TO THE MEDroal SchooI-The Dean, St. Thomas's Hospital Medical School, London, S.E.1 (January 31).

PHYSIOAL CHEMIST to evolve polarographic and other methods suitable for the analysis of plants and supervise their routine use and a PHYSICIST to evolve spectrographic and other methods suitable and a PHYSICIST to evolve spectrographic and other methods suitable for the analysis of plants and supervise their routine use-The Secre(January 31 ).

Lecturer in Chemical Enginefring in the Department of oil Engineering and Refining-The Secretary, The University, Edmund Street, Birmingham 3 (February 1).

LECTURER IN THE DEPARTMENT OF LEATHER INDUSTRIES-The egistrar, The University, Leeds 2 (February 28)

LECTURER IN PHYSIOLOGY-The Secretary, Queen's University, (March 31).

REGIONAL DIRECTOR (West of Scotland) and DIRECTOR OF CENTRAI DEPOT (Western Area) at Glasgow (joint appointment), and a REGIONAL (Eastern Area) (embodylng Plasma Drying Unit) at Eainburgh (joint (Eastern Area) (embodylng Plasma Drying Unit) at Eainburgh (joint aspociation, 10 Duke Street, Edinburgh 1 (April 20).

Professor of PHYSICS-The Principal, Heriot-Watt college, Edinburgh (April 22)

TECHNICAL ASSISTANT (Hæmatology) (non-resident, male or female) for Clinical Laboratory Work-The General Superintendent and Secretary, Royal Inflrmary, Manchester.

AssistanT PHYsIcisT in the Radiotherapy Department-The House Governor, London Hospital, Mile End, London, E.1.

Professor of PHysiology in the University of Ceylon-The Secretary, Universities Bureau of the British Empire, c/o University College, Gower Street, London, W.C.I.

LECTURER IN MATHEMATICS in the Natal University College, Pietermaritzburg-The Secretary, Universities Bureau of the British Empire, c/o University College, Gower Street, London, W.C.1.

CURATOR-LIBRARIAN (experienced) by an Oil Company in Iraq, to take charge of literature and fossil collections in geological lab oratory-The Ministry of Labour and National Service, London Appointments Office, 1-6 Tavistock Square, London, W.C.1, quoting F.A.158.

BIOCHEMIST or CHEMICAL ANALYST (graduate, experienced), and HOSPITAL Or LABORATORY TECHNICIANS, for work with nutritional team in Germany-The Director, Oxford Nutrition Survey, 10 Parks Road, Oxford.

LECTURER (full-time) IN AUTOMOBILI ENGINEERING for Day and Evening work-The Principal, Leicester College of Technology and Commerce, The Newarke, Leicester.

RESEARCH ASSOCIATE-The Secretary, National Institute of Economic and Social Research, 53 Romney Street, London, S.W.1.

\section{REPORTS and other PUBLICATIONS} (not included in the monthly Books Supplement) Great Britain and Ireland

Freshwater Biological Association of the British Empire. Thirteenth Annual Report for the Year ending 31st March 1945. Pp. 42. (Ambleside : Freshwater Biological Association, 1945.) 18. 6d. Ministry of Health: Nurses Salaries Committee. Mental Nurses Notes, No. 4. Pp. 4. (London: H.M. Stationery Office, 1945.) id. Notes, No. 4. Pp. 4. (London: H.M. Stationery Office, 1945.) $1 d$.
net. net. The Journal of the Institute of Metals. Vol. 70, 1944. Edited by N. B. Vaughan. Pp. xlvii $+614+65$ plates. (London: Institute of

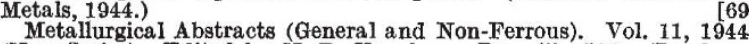
Metallurgical Abstracts (General and Non-Ferrous). Vol. 11, 1944
(New Series). Edited by N. B. Vaughan. Pp. vili +514. (London (New Series). Edited by N. B. Vaughan. Pp. viii +514. (London :
[69 Lecture on Cement and Concrete. By Dr. F. M. Lea. Pp. 30 (London : Royal Institute of Chemistry, 1945.) [138 Lecture on Chemistry and Clothing. By D. A. Clibbens. (First Dalton Memorial Lecture.) Pp. 16. (London: Royal Institute of
Chemistry, 1945.) Chemistry, 1945.)
The Health Services in Austria: Problems of Medical Reconstruction and Rehabilitation. Pp. 40. (London: Association of Austrian Doctors in Great Britain, 1945.) 38.
Ministry of Fuel and Power: Committee on Efficient Use of Fuel Ministry of Fuel and Power: Committee on Efficient Use of Fuel.
Fuel Efficiency Bulletin No. $40:$ Combined Power and Heating. Fuel Efficiency Bulletin No. 42: The Recovery of Waste Heat from Fuel Gases. (London: Ministry of Fuel and Power, 1945.) [259 Catalogues

A Catalogue of Rare and Important Books on Zoology, including some Important Works on Fisheries and the Fine Ornithological Work of John Gould ; Geology, Botany, Agriculture, Forestry, Fruit-Culture and Gardening. (No. 632.) Pp. 92. (London: Bernard Quaritch,

Ltd., 1945.) 6d. Outflts. Pp. vi +242. (London: The British Drug Houses, Ltd., 1945.) 